\title{
Enhancing Service Quality in a Higher Educational Institution: A Case of Undergraduate Students at Sariputta College, Muse, Shan State, Myanmar
}

\author{
Nyartika \\ Assumption University, Bangkok, Thailand
}

\begin{abstract}
In a developing country as Myanmar, the concept of service quality is still not well-known. The researcher is a Myanmar student finalizing his research dissertation and would like to contribute what he had learned in this area for the benefit of his community when finally, he returns to the motherland.
\end{abstract}

In this study, the researcher used the famous SERVQUAL dimensions of service quality namely, tangibles, reliability, responsiveness, assurance, and empathy, and applied to a nonprofit educational establishment in Myanmar. The purpose of the study is to determine the service quality of the establishment with the aim of continuously improving them.

A mixed research methodology was used in the collection and analysis of the data with the results discussed and recommendations.

Finding, the researcher concludes that to improve the college's service quality rating it needs to upgrade its facilities and equipment.

Keywords: Quality Management/ Higher Education/ Private Nonprofit College/ Tangibles, reliability, responsiveness, assurance, and empathy/ Myanmar and China border economic cooperation core zones. 